CLINICAL STUDY

\title{
Genetic variation in receptor protein tyrosine phosphatase $\sigma$ is associated with type 2 diabetes in Swedish Caucasians
}

\author{
Ewa-Carin Långberg, Harvest F Gu, Sofia Nordman, Suad Efendic and Claes-Göran Östenson \\ Department of Molecular Medicine and Surgery, Karolinska Institutet, Rolf Luft Center for Diabetes Research, Karolinska University Hospital Solna, 171 \\ 76 Stockholm, Sweden \\ (Correspondence should be addressed to E-C Långberg; Email: ewa-carin.langberg@ki.se)
}

\begin{abstract}
Objective: Previously, it has been demonstrated that receptor protein tyrosine phosphatase $\sigma(\mathrm{RPTP} \sigma)$ is involved in glucose homeostasis and insulin signaling in several animal models. The aim of this study was to evaluate whether polymorphisms in this gene influence the development of type 2 diabetes (T2D) in humans.

Design: We investigated how genetic variations in the $R P T P \sigma$ gene influence susceptibility to impaired glucose tolerance (IGT) and T2D, in Swedish men and women.

Methods: Genotyping of single nucleotide polymorphisms (SNPs) was performed by dynamic allelespecific hybridization in a total of 1057 Swedish Caucasians including 497 subjects with normal glucose tolerance (NGT), 262 subjects with IGT, and 298 patients with T2D.

Results: SNPs rs1143699, rs4807015, and rs1978237 were found to be associated with T2D. SNP rs1143699 was associated with male T2D patients when compared with NGT controls (odds ratio; $\mathrm{OR}=1.57 ; \mathrm{P}=0.029)$. SNP rs4807015 showed association with T2D patients when compared with NGT controls $(\mathrm{OR}=1.32 ; P=0.025)$. Finally, SNP rs1978237 was associated with $\mathrm{T} 2 \mathrm{D}$ patients when compared with NGT controls $(\mathrm{OR}=1.59 ; \mathrm{P}=0.002)$. Logistic regression analysis demonstrated that for SNP rs1143699 in men, C/C homozygosity conveys an increased risk of T2D $(\mathrm{OR}=2.19$; $P=0.035)$, while SNP rs4807015 was associated with an increased risk of T2D in both men and women $(\mathrm{OR}=1.74 ; P=0.029)$. SNP rs1978237 also demonstrated a risk of T2D in men and women $(\mathrm{OR}=1.59 ; \mathrm{P}=0.026)$.

Conclusions: This study provides evidence for association of SNPs in the RPTP $\sigma$ gene with T2D in Swedish Caucasians. SNPs rs1143699, rs4807015, and rs1978237 confer an increased risk of developing T2D.
\end{abstract}

European Journal of Endocrinology 157 459-464

\section{Introduction}

Type 2 diabetes (T2D) is a multifactorial disease that involves insulin resistance and impaired glucoseinduced insulin release (1). In most patients, T2D results from alterations of several genes, where each of them has a partial and additive effect (2). T2D is also influenced by lifestyle, such as a high calorie intake and sedentary behavior leading to overweight (3). Identification of genes influencing genetic variation in disease offers a better understanding of molecular mechanisms underlying T2D pathogenesis, which is a prerequisite for development of therapeutic methods (4).

We have previously demonstrated that the receptor protein tyrosine phosphatase $\sigma(R P T P \sigma)$ gene, also known as PTP $\sigma$, is overexpressed by $\sim 60 \%$ in pancreatic islets and liver of spontaneously diabetic Goto-Kakizaki (GK) rats that have impaired insulin secretion. When islet RPTP $\sigma$ was inhibited by antisense, improved glucose-induced insulin secretion was seen in GK islets (5). In addition, RPTP $\sigma$ knockout $(-/-)$ mice have shown decreased plasma glucose and insulin levels in the fasted state when compared with wild-type controls. The mice also had increased whole-body insulin sensitivity, suggesting that RPTP $\sigma$ affects insulin signaling in insulin-sensitive tissues (6).

RPTP $\sigma$ has a function in the cellular receptor signaling, which is critical for signal transduction in both normal and pathophysiological conditions (7). It is a member of the leukocyte antigen-related (LAR) RPTP family, which has been suggested to act in key steps of neural development and also in diabetes and cancer (8). LAR, a protein closely related to RPTP $\sigma$, has negative regulatory effects in the insulin signaling pathway when it is overexpressed (9). The RPTP $\sigma$ gene gives rise to several different distinct isoforms (10). PTPs are key regulators of the insulin receptor signal transduction pathway and the $R P T P \sigma$ gene has been shown to be highly expressed in insulin target tissues, such as liver, 
adipose tissue, skeletal muscle, and endothelial cells (11). In humans, the RPTP $\sigma$ gene is located on chromosome $19 \mathrm{p} 13.3$, a region that may influence traits underlying lipid abnormalities associated with T2D (12).

Until now, there has not been a genetic report of RPTP $\sigma$ in T2D patients. We have selected SNPs in the $R P T P \sigma$ gene to study in a Swedish cohort including T2D patients, subjects with impaired glucose tolerance (IGT), and normal glucose tolerance (NGT) control subjects. Our study hypothesis was to evaluate the genetic influence of polymorphisms of the RPTP $\sigma$ gene in development of T2D among Swedish men and women.

\section{Subjects and methods}

\section{Subjects}

The study includes 497 unrelated subjects with NGT (246 men/251 women), 262 subjects with IGT (107/155), and 298 patients with T2D (241/57). All individuals were Swedish Caucasians collected from the Stockholm Diabetes Prevention Program with a baseline study in men 1992-1994 and in women 1996-1998. A follow-up study in about $70 \%$ of the baseline participants was conducted 10 years later (13-15). Patients were diagnosed according to the World Health Organization criteria (1998) (16). NGT control subjects had a mean birth body weight of $3742 \mathrm{~g}$ (3000-5800), body mass index $\leq 26 \mathrm{~kg} / \mathrm{m}^{2}$, and no relatives diagnosed with T2D. All clinical data in T2D patients were used from the baseline study (those diagnosed at baseline and incident cases between baseline and follow-up studies) or at follow-up study (diagnosed at follow-up). The data were not influenced by use of anti-diabetic medication. Clinical parameters for each study group are given in Table 1. All participants gave their informed consent to take part in the study. The procedures followed were in accordance with the declaration of Helsinki II and approved by the ethics committee of Karolinska Hospital. DNA was extracted from peripheral blood using Puregene DNA purification kit (Gentra Systems, Minneapolis, MN, USA).

\section{SNP validation and genotyping}

We selected a total of 28 SNPs within the RPTP $\sigma$ gene from the National Center for Biotechnology Information (USA; http://www.ncbi.nlm.nih.gov/SNP/) database based on validation status, region, and function for our study. SNPs chosen were picked to cover the whole gene. The Tagger program from the International HapMap project (release no. 21) was also used to select and evaluate tagSNPs from genotype data in HapMap (17). Here, pairwise tagging was used together with an $r^{2}$ cutoff of 0.8 and a minor allele frequency of $5 \%$. The majority of the chosen SNPs were captured by tagger.

Validation of 28 chosen SNPs in 32 Swedish DNA samples including 16 T2D patients and 16 NGT controls was performed. Twelve SNPs representing at least $4 \%$ allele frequencies were used for further genotyping. Genotyping was performed by dynamic allele-specific hybridization (DASH) (18). PCR-DASH assay design and SNP genotyping protocol were used as described previously (19). Information on primer and probe sequences used in PCR-DASH assays are available, upon request. All PCRs were run in $20 \mu \mathrm{l}$ volumes using 10-20 ng genomic DNA. Negative controls (water blanks) were included on each plate. For genotyping quality control, the subjects were distributed randomly across plates with the same number of cases and controls per plate. Successful genotype calls were $\geq 95 \%$ and plates were randomly genotyped twice for duplication accuracy, which was calculated to be $98 \%$.

Table 1 Clinical data of Swedish normal glucose tolerance (NGT) control subjects, impaired glucose tolerance (IGT) subjects, and type 2 diabetes (T2D) patients.

\begin{tabular}{|c|c|c|c|c|c|c|}
\hline & \multicolumn{2}{|c|}{ NGT } & \multicolumn{2}{|l|}{ IGT } & \multicolumn{2}{|c|}{ T2D } \\
\hline & Male & Female & Male & Female & Male & Female \\
\hline$n$ & 186 & 252 & 107 & 155 & 232 & 57 \\
\hline Age (years) & $45 \pm 5$ & $47 \pm 5$ & $47 \pm 5$ & $49 \pm 4$ & $52 \pm 6$ & $50 \pm 4$ \\
\hline $\mathrm{BMI}\left(\mathrm{kg} / \mathrm{m}^{2}\right)$ & $23.7 \pm 1.8$ & $22.6 \pm 1.7$ & $29.1 \pm 4.7$ & $29.2 \pm 6.0$ & $29.5 \pm 4.7$ & $31.1 \pm 6.5$ \\
\hline Waist circumference (cm) & $86.1 \pm 5.9$ & $73.9 \pm 4.7$ & $99.1 \pm 9.8$ & $89.3 \pm 12.7$ & $100.7 \pm 10.9$ & $94.8 \pm 13.3$ \\
\hline Waist-hip ratio & $0.87 \pm 0.04$ & $0.77 \pm 0.04$ & $0.93 \pm 0.04$ & $0.84 \pm 0.06$ & $0.95 \pm 0.05$ & $0.87 \pm 0.07$ \\
\hline Systolic BP (mmHg) & $121 \pm 12$ & $115 \pm 13$ & $136 \pm 19$ & $133 \pm 18$ & $138 \pm 17$ & $137 \pm 17$ \\
\hline Diastolic BP (mmHg) & $77 \pm 8$ & $72 \pm 9$ & $85 \pm 11$ & $82 \pm 10$ & $86 \pm 11$ & $83 \pm 9$ \\
\hline $\begin{array}{l}\text { Fasting plasma glucose } \\
(\mathrm{mmol} / \mathrm{l})\end{array}$ & $4.5(4.0-5.0)$ & $4.5 \pm 0.4$ & $5.2(4.6-5.9)$ & $5.2 \pm 0.6$ & $6.6(4.9-8.8)$ & $7.6 \pm 2.2$ \\
\hline $2 \mathrm{~h}$ plasma glucose $(\mathrm{mmol} / \mathrm{l})$ & $4.0(3.1-5.1)$ & $4.1 \pm 1.0$ & $8.7(8.0-9.5)$ & $8.8 \pm 0.8$ & $10.5(6.8-16.2)$ & $13.6 \pm 4.0$ \\
\hline Fasting plasma insulin (mU/I) & $15.5(11.1-21.7)$ & $9.2 \pm 3.6$ & $24.0(15.8-36.5)$ & $15.5 \pm 7.5$ & $25.8(15.6-42.7)$ & $21.8 \pm 13.6$ \\
\hline $2 \mathrm{~h}$ plasma insulin (mU/l) & $35.6(22.2-56.9)$ & $28.5 \pm 12.6$ & 117.4 (70.9-194.2) & $88.3 \pm 69.4$ & $84.8(42.9-167.6)$ & $73.8 \pm 62.4$ \\
\hline HOMA-IR index ${ }^{a}$ & $3.3 \pm 1.2$ & $1.9 \pm 0.8$ & $6.2 \pm 2.7$ & $3.7 \pm 2.0$ & $9.1 \pm 6.4$ & $7.4 \pm 5.3$ \\
\hline
\end{tabular}

All data are means \pm S.D. or geometric mean (s.D. range).

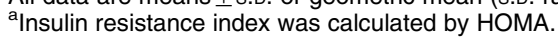




\section{Calculations and statistical analysis}

The homeostasis model assessment (HOMA) was used to assess insulin resistance. Based on fasting glucose and insulin levels, it was calculated according to the following equation: fasting plasma glucose $(\mathrm{mmol} / \mathrm{l}) \times$ fasting plasma insulin $(\mathrm{mU} / \mathrm{ml}) / 22.5$ (20).

Normal probability plots were created and parameter distributions were transformed to natural logarithm as required to improve skewness and to obtain a normal distribution before performing statistical analysis. Homogeneity of variances was tested by Levene's test. Genotype and allele distribution were compared between cases (IGT subjects and/or T2D patients) and NGT control subjects using $\chi^{2}$-test. OR and 95\% confidence intervals (CI) were calculated to test for relative risk for association. Testing for differences in clinical parameters between genotype groups was performed using ANOVA and covariance analysis adjusting for age. $P$ values less than 0.05 were interpreted as statistically significant. Multivariate logistic regression analysis was used to predict the susceptibility to T2D between case and control subjects. Adjustments for age, sex, BMI, and blood pressure (where appropriate) were applied. The effects of the SNPs were tested individually and/or as haplotypes. Linkage disequilibrium (LD) and haplotype frequencies were calculated using Arlequin (21). LD between different markers/SNPs was summarized using $\left|D^{\prime}\right|$. Haplotypes prevalent at 5\% were used for further haplotype analysis. All statistical analyses were performed using Statistica version 7.1 (Statsoft Inc., Tulsa, OK, USA) and/or Biomedical package (BMDP) version 1.1 (BMDP Statistical Software Inc., Los Angeles, CA, USA).

\section{Results}

A total of 12 valid SNPs were genotyped in the RPTP $\sigma$ gene and all of them were in Hardy-Weinberg equilibrium $(P>0.05)$. Genotype and allele frequencies of all valid
SNPs in NGT and IGT subjects and T2D patients are presented in Table 2. The results are focused on SNPs rs1143699, rs4807015, and rs1978237, since the remaining SNPs studied did not show significant allelic association between study groups.

\section{SNP rs1143699}

SNP rs1143699 showed significant allelic association with male T2D patients when compared with NGT controls $(0.89$ vs 0.84$)$, where the major allele $C$ was present at a higher frequency in $\mathrm{T} 2 \mathrm{D}(P=0.029$; $\mathrm{OR}=$ 1.57; 95\% CI=1.05-2.36; Table 3). No allelic association could be noted when comparing male IGT subjects and controls, or in female, IGT and T2D, when compared with controls. Comparison of genotypes and quantitative traits within groups was performed by ANOVA and covariance analysis adjusting for age. No significant associations with quantitative traits were detected (data not shown). Multivariate logistic regression analysis of SNP rs1143699 with adjustments for age, BMI, and blood pressure indicated that in men the $\mathrm{C} / \mathrm{C}$ genotype was significantly associated with $\mathrm{T} 2 \mathrm{D}$ when compared with $\mathrm{C} / \mathrm{T}+\mathrm{T} / \mathrm{T}(P=0.035$; $\mathrm{OR}=2.19 ; 95 \% \mathrm{CI}=1.055-4.523$; Table 4 ).

\section{SNP rs4807015}

A significant difference in allele frequency was found in SNP rs4807015 comparing all T2D patients with NGT controls (0.49 vs 0.56$)$, $\mathrm{C}$ being the major allele present at a lower frequency in $\mathrm{T} 2 \mathrm{D}(P=0.025$; $\mathrm{OR}=1.32$; 95\% CI =1.034-1.678; Table 3). Multiple logistic regression analysis showed that this SNP was associated with increased risk of $\mathrm{T} 2 \mathrm{D}$ in men and women carrying the $\mathrm{C} / \mathrm{C}$ genotype $(P=0.029$; $\mathrm{OR}=1.74$; $95 \% \mathrm{CI}=1.058-2.865)$ adjusted for age and blood pressure (Table 5). When adding sex as a covariate to the model, this association was no longer seen. In IGT

Table 2 Genotype and allele frequencies of 12 single nucleotide polymorphisms (SNPs) in the RPTP gene in Swedish normal glucose tolerance (NGT), impaired glucose tolerance (IGT) subjects, and type 2 diabetes (T2D) patients.

\begin{tabular}{|c|c|c|c|c|c|c|c|c|c|c|}
\hline \multirow[b]{2}{*}{ SNP ID } & \multirow[b]{2}{*}{$\begin{array}{c}\text { Contig } \\
\text { position }^{a}\end{array}$} & \multirow[b]{2}{*}{ SNP type } & \multirow[b]{2}{*}{ Region } & \multirow[b]{2}{*}{ Function } & \multicolumn{3}{|c|}{ Genotype frequencies (\%) } & \multicolumn{3}{|c|}{ Allele frequencies (\%) } \\
\hline & & & & & NGT & IGT & T2D & NGT & IGT & T2D \\
\hline rs1017092 & 5214986 & $\mathrm{R}=\mathrm{G} / \mathrm{A}$ & Intron 1 & Intronic & $47 / 45 / 8$ & $49 / 41 / 10$ & $49 / 45 / 6$ & 69/31 & $70 / 30$ & $72 / 28$ \\
\hline rs1034917 & 5214384 & $\mathrm{Y}=\mathrm{C} / \mathrm{T}$ & Intron 1 & Intronic & $69 / 28 / 3$ & $67 / 28 / 5$ & $72 / 25 / 3$ & $83 / 17$ & $81 / 19$ & $85 / 15$ \\
\hline rs1141371 & 5213571 & $\mathrm{M}=\mathrm{A} / \mathrm{C}$ & Exon 3 & Synonymous & $64 / 32 / 4$ & $63 / 33 / 4$ & $60 / 36 / 4$ & $80 / 20$ & $80 / 20$ & $78 / 22$ \\
\hline rs1034863 & 5207751 & $\mathrm{Y}=\mathrm{C} / \mathrm{T}$ & Intron 3 & Intronic & $81 / 18 / 1$ & $79 / 21 / 0$ & $80 / 19 / 1$ & $90 / 10$ & $89 / 11$ & $90 / 10$ \\
\hline rs886936 & 5193432 & $\mathrm{R}=\mathrm{G} / \mathrm{A}$ & Intron 8 & Intronic & $31 / 48 / 21$ & $36 / 42 / 22$ & $30 / 54 / 16$ & $55 / 45$ & $57 / 43$ & $57 / 43$ \\
\hline rs10518243 & 5175958 & $\mathrm{R}=\mathrm{G} / \mathrm{A}$ & Intron 12 & Intronic & $83 / 15 / 2$ & $78 / 20 / 2$ & $81 / 18 / 1$ & $91 / 09$ & $88 / 12$ & $90 / 10$ \\
\hline rs4807015 & 5171135 & $\mathrm{Y}=\mathrm{C} / \mathrm{T}$ & Intron 13 & Intronic & $31 / 50 / 19$ & $30 / 45 / 25$ & $27 / 44 / 29$ & $56 / 44$ & $52 / 48$ & $49 / 51$ \\
\hline rs2230611 & 5152482 & $\mathrm{M}=\mathrm{C} / \mathrm{A}$ & Exon 30 & Synonymous & $80 / 18 / 2$ & $80 / 19 / 1$ & $79 / 20 / 1$ & $89 / 11$ & $89 / 11$ & $89 / 11$ \\
\hline rs1143698 & 5150782 & $\mathrm{Y}=\mathrm{C} / \mathrm{T}$ & Exon 33 & Synonymous & $63 / 30 / 7$ & $66 / 27 / 7$ & $6 / 30 / 9$ & $78 / 22$ & $80 / 20$ & $76 / 24$ \\
\hline rs1143699 & 5159762 & $\mathrm{Y}=\mathrm{C} / \mathrm{T}$ & Exon 33 & Synonymous & $75 / 24 / 1$ & $77 / 22 / 1$ & $80 / 19 / 1$ & $87 / 13$ & $88 / 12$ & $89 / 11$ \\
\hline rs1978237 & 5149641 & $\mathrm{~S}=\mathrm{G} / \mathrm{C}$ & Intron 34 & Intronic & $51.5 / 41.5 / 7$ & $49 / 43 / 8$ & $65 / 31 / 4$ & $72 / 28$ & $70 / 30$ & $80 / 20$ \\
\hline rs1143700 & 5146775 & $\mathrm{Y}=\mathrm{C} / \mathrm{T}$ & Exon 37 & $3^{\prime}$-UTR & $69 / 28 / 3$ & $66 / 30 / 4$ & $67 / 29 / 4$ & $83 / 17$ & $81 / 19$ & $81 / 19$ \\
\hline
\end{tabular}

Genotype frequencies are presented as homozygous major allele/heterozygotes/homozygous minor allele. Allele frequencies are presented as major allele first.

${ }^{2}$ The contig ID number at NCBI is NT_011255/NW_927173. 
Table 3 Allelic association of single nucleotide polymorphism (SNP) rs1143699, rs4807015 and rs1978237 in normal glucose tolerance (NGT), impaired glucose tolerance (IGT) subjects, and type 2 diabetes (T2D) patients.

\begin{tabular}{|c|c|c|c|c|c|c|}
\hline \multirow[b]{2}{*}{ SNP ID } & \multirow[b]{2}{*}{ Sex } & \multicolumn{3}{|c|}{ Allele frequencies (\%) } & \multirow{2}{*}{$\begin{array}{l}\boldsymbol{P} \text { value } \\
\text { T2D }\end{array}$} & \multirow{2}{*}{$\begin{array}{c}\text { OR }(95 \% \mathrm{Cl}) \\
\text { T2D }\end{array}$} \\
\hline & & NGT & IGT & T2D & & \\
\hline \multirow[t]{3}{*}{ rs1143699 } & M & $\mathrm{C} 84 / \mathrm{T} 16$ & $\mathrm{C} 86 / \mathrm{T} 14$ & $\mathrm{C} 89 / \mathrm{T} 11$ & 0.029 & $1.57(1.05-2.36)$ \\
\hline & $\mathrm{F}$ & $\mathrm{C} 89 / \mathrm{T} 11$ & C89/T11 & $\mathrm{C} 89 / \mathrm{T} 11$ & NS & - \\
\hline & $M+F$ & C87/T13 & C88/T12 & C89/T11 & NS & - \\
\hline \multirow[t]{3}{*}{ rs4807015 } & $\mathrm{M}$ & C51/T49 & C49/T51 & C47/T53 & NS & - \\
\hline & $\mathrm{F}$ & C59/T41 & C55/T45 & C53/T47 & NS & - \\
\hline & $M+F$ & $\mathrm{C} 56 / \mathrm{T} 44$ & $\mathrm{C} 52 / \mathrm{T} 48$ & C49/T51 & 0.025 & $1.32(1.03-1.68)$ \\
\hline \multirow[t]{3}{*}{ rs1978237 } & $\mathrm{M}$ & G71/C29 & G65/C35 & G79/C31 & NS & - \\
\hline & $\mathrm{F}$ & $\mathrm{G} 73 / \mathrm{C} 27$ & G74/C26 & G78/C22 & NS & - \\
\hline & $M+F$ & G72/C28 & G70/C30 & G80/C20 & 0.002 & $1.59(1.18-2.13)$ \\
\hline
\end{tabular}

$P$ value represents allele frequency difference between NGT and T2D. NS, not significant.

men and women subjects, the association was not significant (data not shown).

\section{SNP rs1978237}

SNP rs1978237 showed significant allelic association with all T2D patients when compared with NGT controls ( 0.80 vs 0.72 ), where the major allele $\mathrm{G}$ was present at a higher frequency in $\mathrm{T} 2 \mathrm{D}(\mathrm{P}=0.002 ; \mathrm{OR}=$ 1.59; 95\% CI =1.184-2.126; Table 3). Multiple logistic regression analysis showed that this SNP was associated with increased risk of T2D in men and women carrying the $\mathrm{G} / \mathrm{G}$ genotype $(P=0.026 ; \mathrm{OR}=1.591 ; 95 \% \mathrm{CI}=$ 1.056-2.398) adjusted for age, BMI, and blood pressure (Table 6). A similar result was retrieved when adding the covariate sex to the analysis. In IGT men and women subjects, the association was not significant.

\section{LD}

LD between SNPs was found to be in concordance with HapMap data (release no. 21). We found three common haplotypes for SNP rs1143699, rs4807015, and rs1978237 with a frequency above 5\%. However, there was no significant difference in haplotype distribution between groups for SNP rs1143699, rs4807015, and rs1978237 (data not shown).

\section{Discussion}

We investigated the genetic influence of SNPs for RPTP $\sigma$ in Swedish NGT subjects, IGT subjects, and T2D patients, and found that three polymorphisms confer susceptibility to development of T2D. SNP rs1143699 was associated with an increased risk of T2D in male patients carrying the $\mathrm{C} / \mathrm{C}$ genotype. SNP rs4807015 and rs1978237 was associated with an increased risk of T2D in both male and female patients. The moderate OR for these three SNPs, which were around 1.3-1.6, support the hypothesis that there is restricted influence of a single SNP in T2D. However, when comparing sample groups and adjusting for clinical features separating them (age, BMI, and blood pressure), the relative risk to develop T2D was even more increased for SNP rs1143699 (OR 2.2), but still the same for SNP rs1978237 (OR 1.6). SNP rs4807015 showed the same trend in results. This is a truer reflection of how the different SNPs studied contribute to susceptibility of T2D, since the data have been adjusted for covariates. In all three SNPs, the allele being responsible for the increased risk was the major allele.

SNP rs1143699 is located in exon 33, which is within the PTP catalytic (PTPc) domain, an important functional part of the $R P T P \sigma$ gene being involved in phosphorylation of interacting proteins. SNP rs4807015 is located in intron 13 and rs1978237 in intron 34. In other genes, intronic SNPs have been suggested to contribute to gene expression, and therefore, this is a possible explanation for the role of SNP rs4807015 and rs1978237 (22-24). Finally, susceptibility is often a result of the combined action of many different variants in a gene, one example being calpain10 in T2D (25). These considerations need to be emphasized when interpreting association data of $R P T P \sigma$.

We did not detect any association between genotype groups and clinical phenotypes for the SNPs in our study. This is most probably because our male patient group contains clinical data at baseline also for patients

Table 4 Association of single nucleotide polymorphism (SNP) rs1143699 C allele in type 2 diabetes (T2D) men.

\begin{tabular}{lccr}
\hline Variable & OR & 95\% Cl & P value \\
\hline Age & 1.17 & $1.10-1.25$ & $<0.001$ \\
BMI & 2.12 & $1.74-2.57$ & $<0.001$ \\
Systolic BP & 1.04 & $1.00-1.08$ & $<0.001$ \\
Diastolic BP & 0.99 & $0.94-1.03$ & 0.533 \\
SNP rs1143699 C/C & 2.19 & $1.06-4.52$ & 0.035 \\
versus C/T+T/T & & &
\end{tabular}

Multivariate logistic regression analysis was used to examine independent variables associated with T2D in Swedish T2D men when compared with NGT controls. Odds ratio (95\% confidence interval) and $P$ values for multiple logistic analyses including age, BMI, and blood pressure in the model are shown. 
Table 5 Association of single nucleotide polymorphism (SNP) rs4807015 G allele in type 2 diabetes (T2D) men and women.

\begin{tabular}{lccr}
\hline Variable & OR & 95\% Cl & P value \\
\hline Age & 1.15 & $1.10-1.21$ & $<0.001$ \\
Systolic BP & 1.06 & $1.04-1.09$ & $<0.001$ \\
Diastolic BP & 1.03 & $1.00-1.06$ & 0.093 \\
SNP rs4807015 G/G & 1.74 & $1.06-2.86$ & 0.029 \\
$\quad$ versus C/G + C/C & & & \\
\hline
\end{tabular}

Multivariate logistic regression analysis was used to examine independent variables associated with T2D in Swedish T2D women and men when compared with NGT controls. Odds ratio (95\% confidence interval) and $P$ values for multiple logistic analyses including age and blood pressure in the model are shown.

who were diagnosed with T2D during the 10 years between baseline and follow-up studies. This subgroup of T2D men did not have diabetes at baseline, which explains the low fasting plasma glucose in the diabetes group $(6.6 \mathrm{mmol} / \mathrm{l})$. However, we chose not to include follow-up data of these patients, since anti-diabetic drugs and lifestyle changes would then be affecting the quantitative traits of the patients.

LAR is a member of the same PTP family as RPTP $\sigma$ and has a role in negative modulation of insulin receptor signaling (26). Increased activity of LAR or related PTPs in insulin target tissues could contribute to development of insulin resistance (27). The fact that RPTP $\sigma$ shows similarity to LAR, $85 \%$ at amino acid level, and is expressed to a higher level than LAR in insulin-sensitive tissues, makes this protein a possible candidate for regulating insulin signaling and for playing a role in glucose homeostasis (28). To our knowledge, the present study is the first genetic investigation of $R P T P \sigma$ in T2D. However, there is a genetic association study of an SNP in the promoter region of $L A R$ in two non-diabetic populations in Italy (29), showing association with diabetes-related characteristics (29). Thus, LAR and RPTP $\sigma$ seem to be important genes in the development of T2D.

SNP rs1143699 was found to be associated with T2D in men but not in women, suggesting that gender differences may be an important factor in the genetic influence of RPTP $\sigma$ in T2D. Our group and others have previously shown that there are sex differences in

Table 6 Association of single nucleotide polymorphism (SNP) rs1978237 G allele in type 2 diabetes (T2D) men and women.

\begin{tabular}{lccr}
\hline Variable & OR & $\mathbf{9 5 \%} \mathbf{C l}$ & $\boldsymbol{P}$ value \\
\hline Age & 1.09 & $1.05-1.14$ & $<0.001$ \\
BMI & 1.92 & $1.74-2.13$ & $<0.001$ \\
Systolic BP & 1.04 & $1.01-1.06$ & 0.001 \\
Diastolic BP & 1.01 & $0.98-1.05$ & 0.436 \\
SNP rs1978237 G/G & 1.59 & $1.06-2.40$ & 0.026 \\
versus C/G + G/G & & & \\
\hline
\end{tabular}

Multivariate logistic regression analysis was used to examine independent variables associated with T2D in Swedish T2D women and men when compared with NGT controls. Odds ratio (95\% confidence interval) and $P$ values for multiple logistic analyses including age, BMI and blood pressure in the model are shown. genetic association with T2D. Polymorphisms in the insulin-degrading enzyme gene are associated with increased BMI and insulin resistance in men but not in women (30). Also, a polymorphism in neuropeptide $\mathrm{Y}$, a gene involved in satiety and body weight, is related to IGT and T2D in men (31). Thus, sex specificity could be an important confounding factor in analyzing genetics of T2D and related disorders (30-34).

In conclusion, this study provides evidence that three polymorphisms in the RPTP $\sigma$ gene are associated with the development of T2D in Swedish Caucasians, which support our hypothesis that the RPTP $\sigma$ gene may be important for the development of $\mathrm{T} 2 \mathrm{D}$ in humans. Further investigation in other populations and determination of the functional influence of variation in RPTP $\sigma$ are necessary to make conclusive implications.

\section{Acknowledgements}

This study was supported by the Swedish Research Council, the Swedish Diabetes Association, Novo Nordisk Scandinavia, GlaxoSmithKline, Novo Nordisk Consortium, and the Loo and Hans Osterman foundation. The authors thank all subjects for participating in the present study. The excellent assistance of Camilla Lagerberg, Yvonne Strömberg, Elisabeth Norén-Krog, and Agneta Hilding is greatly acknowledged.

\section{References}

1 Schinner S, Scherbaum WA, Bornstein SR \& Barthel A. Molecular mechanisms of insulin resistance. Diabetic Medicine 200522 674-682.

2 Luna MTT. Genes and Type 2 diabetes mellitus. Archives of Medical Research 200536 210-222.

3 Simpson RW, Shaw JE \& Zimmet PZ. The prevention of Type 2 diabetes - lifestyle change or pharmacotherapy? A challenge for the 21st century Diabetes Research and Clinical Practice 200359 165-180.

4 McCarthy MI. Progress in defining the molecular basis of Type 2 diabetes mellitus trough susceptibility-gene identification. Human Molecular Genetics 200413 R33-R41.

5 Östenson C-G, Sandberg-Nordqvist A-C, Chen J, Hällbrink M, Rotin D, Langel Ü \& Efendic S. Overexpression of protein-tyrosine phosphatase PTP is linked to impaired glucose-induced insulin secretion in hereditary diabetic Goto-Kakizaki rats. Biochemical and Biophysical Research Communications 2002291 945-950.

6 Chagnon MJ, Elchebly M, Uetani N, Dombrowski L, Cheng A, Mooney RA, Marette A \& Tremblay M. Altered glucose homeostasis in mice lacking the receptor protein tyrosine phosphatase sigma. Canadian Journal of Physiology and Pharmacology $2006 \mathbf{8 4} 755-763$.

7 Andersen JN, Jansen PG, Echwald SM, Morstensen OH, Fukada T, del Vecchio R, Tonks NK \& Møller NPH. A genomic perspective on protein tyrosine phosphatases: gene structure, pseudogenes, and genetic disease linkage. FASEB Journal 200418 8-30.

8 Chagnon MJ, Uetani N \& Tremblay ML. Functional significance of the LAR receptor protein tyrosine phosphatase family in development of disease. Biochemistry and Cell Biology 200482 664-675. 
9 Zhang W-R, Li P-M, Oswald MA \& Goldstein B. Modulation of insulin signal transduction by eutopic overexpression of the receptor-type protein-tyrosine phosphatase LAR. Molecular Endocrinology $2006 \mathbf{1 0} 575-584$.

10 Pulido R, Serra-Pages C, Tang M \& Streuli M. The LAR/PTP delta/PTP sigma subfamily of transmembrane protein-tyrosinephosphatases: multiple human LAR, PTP delta, PTP sigma isoforms are expressed in a tissue-specific manner and associate with the LAR-interacting protein LIP.1. PNAS 199592 11686-11690.

11 Norris K, Norris F, Kono DH, Vestergaard H, Pedersen O, Theofilopoulos AN \& Møller NPH. Expression of protein-tyrosine phosphatases in the major insulin target tissues. FEBS Letters 1997415 243-248.

12 Malhotra A, Wolford JK \& American Diabetes Association GENNID Study Group. Analysis of quantitative traits in the genetics of NIDDM (GENNID) study. Diabetes 200554 3007-3014.

13 Carlsson S, Persson P-G, Alvarsson M, Efendic S, Norman A, Svanström L, Östenson C-G \& Grill V. Weight history, glucose tolerance and insulin levels in middle-aged Swedish men. American Journal of Epidemiology 1998148 539-545.

14 Grill V, Persson G, Carlsson S, Norman A, Alvarsson M, Östenson C-G, Svanström L \& Efendic S. Family history of diabetes in middle-aged Swedish men is a gender unrelated factor which is associated with insulinopenia in newly diagnosed diabetic subjects. Diabetologia 199942 15-23.

15 Agardh EE, Ahlbom A, Andersson T, Efendic S, Grill V, Hallqvist J, Norman A \& Östenson C-G. Work stress and low sense of coherence is associated with Type 2 diabetes in middle-aged Swedish women. Diabetes Care 200326 719-724.

16 Alberti KG \& Zimmet P. Definition, diagnosis and classification of diabetes mellitus and its complications. Part 1: Diagnosis and classification of diabetes mellitus provisional report of a WHO consultation. Diabetic Medicine 199815539.

17 The International HapMap Consortium. A haplotype map of the human genome. Nature 2005437 1299-1320.

18 Howell WM, Jobs M, Gyllensten U \& Brookes AJ. Dynamic allelespecific hybridization: a new method for scoring single nucleotide polymorphisms. Nature Biotechnology 199917 87-88.

19 Prince JA, Feuk L, Howell WM, Jobs M, Emahazion T, Blennow K \& Brookes AJ. Robust and accurate single nucleotide polymorphism genotyping by dynamic allele-specific hybridization (DASH): design criteria and assay validation. Genome Research $200111229-239$.

20 Matthews DR, Rudenski AS, Naylor BA, Treacher DF \& Turner RC. Homeostasis model assessment: insulin resistance and beta-cell function from fasting plasma glucose and insulin concentrations in man. Diabetologia $1985 \mathbf{2 8} 412-419$.

21 Schneider S, Roessli D \& Excoffier L. (2000) Arlequin: A software for population genetics data analysis. Version 2.0. Genetics and Biometry Lab, Department of Anthropology, University of Geneva.

22 Ma J, Möllsten A, Falkhammar H, Brismar K, Dahlquist G, Efendic D \& Gu HF. Genetic association of the adiponectin polymorphisms in type 1 diabetes with and without diabetic nephropathy. Journal of Diabetic Complications 200721 28-33.

23 Horikawa Y, Oda N, Cox NJ, Li X, Orho-Melander M, Hara M, Hinokio Y, Lindner TH, Mashima H, Schwarz PEH, del BosquePlata L, Horikawa Y, Oda Y, Yoshiuchi I, Colilla S, Polonsky KS, Wei S, Concannon P, Iwasaki N, Schulze J, Baier LJ, Bogardus C, Groop L, Boerwinkle E, Hanis CL \& Bell GI. Genetic variation in the gene encoding calpain-10 is associated with type 2 diabetes mellitus. Nature Genetics 200026 163-175.
24 Hara K, Boutin P, Mori Y, Tobe K, Dina C, Yasuda K, Yamauchi T, Otabe S, Okada T, Eto K, Kadowaki H, Hagura R, Akanuma Y, Yazaki Y, Nagai R, Taniyama M, Matsubara K, Yoda M, Nakano Y, Kimura S, Tomita M, Kimura S, Ito C, Froguel P \& Kadowaki T. Genetic variation in the gene encoding adiponectin is associated with an increased risk of type 2 diabetes in the Japanese population. Diabetes $200251536-540$.

25 Baier LJ, Paskasari AP, Yang X, Pratley RE, Hanson RL, Shen G-Q, Mott D, Knowler WC, Cox NJ, Horikawa Y, Oda N, Bell GI \& Bogardus C. A calpain-10 gene polymorphism is associated with reduced muscle mRNA levels and insulin resistance. Journal of Clinical Investigation 2000106 R69-R73.

26 Ren J-M, Li P-M, Zhang W-R, Sweet LJ, Cline G, Shulman GI, Livingston JN \& Goldstein B. Transgenic mice deficient in the LAR protein-tyrosine phosphatase exhibit profound defects in glucose homeostasis. Diabetes $199847493-497$.

27 Zabolotny JM, Kim Y-B, Peroni OD, Kim JK, Pani MA, Boss O, Klaman LD, Kamatkar S, Shulman GI, Kahn BB \& Neel BG. Overexpression of the LAR (leukocyte antigen-related) proteintyrosine phosphatase in muscle causes insulin resistance. PNAS $2001985187-5192$.

28 Cheng A, Dubé N, Gu F \& Tremblay ML. Coordinated action of protein tyrosine phosphatases in insulin signal transduction. European Journal of Biochemistry 2002269 1050-1059.

29 Miscio G, Tassi V, Coco A, Soccio T, Di Paola R, Prudente S, Baratta R, Frittitta L, Ludovico O, Padovano L, Dallapiccola B, Di Mario U, De Cosmo S \& Trischitta V. The allelic variant of LAR gene promoter $-127 \mathrm{bp} \mathrm{T}$ to $\mathrm{A}$ is associated with reduced risk of obesity and other features related to insulin resistance. Journal of Molecular Medicine 200482 459-466.

30 Gu HF, Efendic S, Nordman S, Östenson C-G, Brismar K, Brookes AJ \& Prince JA. Quantitative trait loci near the insulin-degrading enzyme (IDE) gene contribute to variation in plasma insulin levels. Diabetes 200453 2137-2142.

31 Nordman S, Ding B, Östenson C-G, Kärvestedt L, Brismar K, Efendic S \& Gu HF. Leu7Pro polymorphism in the neuropeptide Y (NPY) gene is associated with impaired glucose tolerance and Type 2 diabetes in Swedish men. Experimental and Clinical Endocrinology and Diabetes 2005205 282-287.

32 O’Donnell CJ, Lindpaintner K, Larson MG, Rao VS, Ordovas JM, Schaefer EJ, Myers RH \& Levy D. Evidence for association and genetic linkage of the angiotensin-converting enzyme locus with hypertension and blood pressure in men but not in women in the Framingham Heart Study. Circulation 199897 1766-1772.

33 Wittrup HH, Tybjaerg-Hansen A, Steffensen R, Deeb SS, Brunzell JD, Jensen G \& Nordestgaard BG. Mutations in the lipoprotein lipase gene associated with ischemic heart disease in men: the Copenhagen city heart study. Arteriosclerosis, Thrombosis, and Vascular Biology 199919 1535-1540.

34 McCarthy JJ, Meyer J, Moliterno DJ, Newby LK, Rogers WJ \& Topol EJ. Evidence for substantial effect modification by gender in a large-scale genetic association study of the metabolic syndrome among coronary heart disease patients. Human Genetics 2003 $11487-98$.

Received 22 February 2007

Accepted 26 July 2007 